\title{
INVESTIGATING THE ROLE OF PRAGMATIC CONNECTIVES IN JOURNALISTIC TEXTUAL GENRES
}

\author{
Janice Helena Chaves Marinho* \\ Gustavo Ximenes Cunha** \\ Universidade Federal de Minas Gerais \\ Faculdade de Letras \\ Belo Horizonte, MG, Brasil
}

\begin{abstract}
This paper examines the use of pragmatic connectives in journalistic texts, aiming at understanding issues involved in discourse articulation. The data we are working on is composed by opinion texts and news (written in Brazilian Portuguese) produced by proficient writers and published in a diary newspaper. Based on the Modular Approach to Discourse Analysis, we assume that the study of pragmatic connectives must be integrated in a global model of the complexity of the discourse organization. Thus, we present the description of the relational organization form of these texts, since this organization form deals with discursive relations as well as with the contributions of pragmatic connectives to their interpretation. Then, through the description of the relational organization of these texts, we discuss the observable differences between the genres through the use of pragmatic connective
\end{abstract}

Key-words: Journalistic genres. Modular approach. Pragmatic connectives.

\section{INTRODUCTION}

The interest on the use of pragmatic connectives in texts is due to the fact that these lexical expressions - studied under different labels, such as discourse markers, cue phrases, discourse connectives, pragmatic particles, text relation marker, and so on (FRASER, 1999, 2005) - play a role in discourse organization and interpretation, although their specific contribution to it is not yet very clear and their definition varies according to the theoretical framework. Therefore, our starting point in this paper is a discussion about what the pragmatic connectives are considered to be. In this discussion, we will briefly mention approaches that have theoretical affinities with the theoretical framework of this paper, the Modular Approach to Discourse Analysis.

Van Dijk (1979), discussing the pragmatic connective functions, classified the discursive connectives according to the type of relations they expressed. Thus, he labeled them pragmatic connectives if their function is related to the expression of relationships

\footnotetext{
* Doutora em Linguística. Professora aposentada da Faculdade de Letras da UFMG e professora permanente do Programa de Pós-Graduação em Estudos Linguísticos da UFMG. E-mail: janicehelena.chaves@gmail.com.

** Doutor em Linguística. Professor adjunto da Faculdade de Letras da UFMG e professor permanente do Programa de Pós-Graduação em Estudos Linguísticos da UFMG. ORCID: <http://orcid.org/0000-00019953-1204>. E-mail: ximenescunha@yahoo.com.br.
} 
between speech acts, and he called semantic connectives those which express relationships between facts denoted by propositions or by sentences.

Ducrot, one of the first researchers who presented the description of the core procedural meaning of discourse markers (DUCROT et al., 1980), claimed that these markers are morphemes that have a function in the relationship of discourse units and that contain semantic instructions in which is inscribed the nature of the argumentative orientation they attribute to the utterances.

Schiffrin (1987), concerned with elements which mark "sequentially-dependent units of discourse", analyzed in detail expressions she labeled discourse markers, as they occur in unstructured interview conversations. These expressions are: and, because, but, I mean, now, oh, or, so, then, well, and y'know. She had also considered as discourse markers verbs (such as see, look, and listen), deictics (such as here and there), interjections (such as gosh and boy), meta-talk (such as this is the point and what I mean $i s$ ), and quantifier phrases (such as anyway, anyhow, and whatever). She was interested in investigating the ways in which discourse markers function to contribute to discourse coherence. Considering that coherence is constructed through relations between adjacent units in discourse, she proposed a model of coherence in which there are five distinct and separate planes, each of them with its own type of coherence. She claimed that discourse markers typically provide contextual coordinates for an utterance by locating the utterance on one or more planes of talk of this discourse model, by indexing the utterances to the speaker, the hearer, or both, and by indexing the utterances to prior and/or subsequent discourse. Thus, she saw discourse markers as elements that has an integrative function in discourse and hence contribute to discourse coherence.

Blakemore (1992), who worked within the Relevance Theory framework, proposed that discourse connectives should be considered as expressions that impose semantic constraints on implicatures. She claimed that they do not have a conceptual representation but have only a procedural meaning, which consists of instructions about how to manipulate the conceptual representation of the utterance. So, discourse connectives should be analyzed as linguistically specified constraints on contexts.

Working within this same relevance-theoretic framework, Moeschler $(1998,2005)$ proposed that pragmatic connectives have essentially an interpretative function. They play a role in facilitating the treatment of information - their function then is to minimize the cognitive efforts - and they also play a role in the interpretation level - their function is to determine the contextual effects of the utterance. Researches working with the framework of Rhetorical Structure Theory (RST) (originally developed as part of studies of computer-based text generation) analyzed discourse connectives as part of the more general analysis of discourse coherence - how speakers and hearers jointly integrate forms, meaning, and actions to make overall sense out of what is said (MANN; THOMPSON, 1986, 1988). As Mann and Taboada note on the RST website, this theoretical framework intended to offer an explanation of the coherence of texts:

\footnotetext{
One formulation of coherence is that it is the absence of non-sequiturs and gaps. That is, for every part of a coherent text, there is some function, some plausible reason for its presence, evident to readers, and furthermore, there is no sense that some parts are somehow missing. RST focuses on the first part - an evident role for every part (MANN; TABOADA, 2015).
} 
According to Taboada (2006), RST provides the analyst with a systematic way for annotating a text. The analysis is usually done by reading the text and constructing a diagram, equivalent to a set of judgments that the analyst has made, that can be explicitly identified, using the relations ${ }^{1}$ and their definitions. Every relation is defined in terms of intentions that lead authors to use that particular relation. A RST diagram provides a view of some of the author's purposes or intentions for including each part.

The recognition of the relations is often, but not always, due to the presence of a discourse marker, viewed as a rhetorical relation marker. According to Mann and Thompson (1986, p. 69), "every language has conjunction morphemes analogous to because, therefore, however, etc., whose sole function it is to mark relationships between the conceptions conveyed by two parts of a text". In this approach, the discourse connectives are not understood as essential for the discourse interpretation, and the authors who work in this area do not aim to develop in depth studies of specific connectives. Their main interest lies specifically in the identification of rhetorical relations (or relational propositions). The apparent lack of interest of RST in the study of connectives finds two reasons. The first is that the emergence of rhetorical relations is considered to be independent of any sign. As Mann and Thompson (1986, p. 69) argue, "relational propositions arise in a text independently of any specific signals of their existence". The other reason is that the same connective could signal different relationships, as Taboada notes (2006, p. 21): "signaling, when present, is never sufficient to identify one particular relation. Frequent signals, such $a s$ and, so, and even verbal tense or (non-)finiteness, appear in multiple relations, rendering the signaling ambiguous as to the relation indicated". Anyway, despite those caveats, in RST connectives are viewed as elements that "guide the text receiver in the recognition of these relations" (TABOADA, 2006, p. 2).

Fraser (1999), in an attempt to clarify the status of discourse markers, defined them as a class of lexical expressions - drawn primarily from the syntactic classes of conjunctions, adverbs, and prepositional phrases - which signal a relationship between the interpretation of the segment they introduce (S2) and the prior segment (S1). According to the author, discourse markers constitute a pragmatic class since they contribute to the interpretation of an utterance rather than to the interpretation of its propositional content. He proposed that there are two types of discourse markers according to the role they play in discourse: (1) those that relate aspects of the explicit message conveyed by S2 with aspects of a message, direct or indirect, associated with S1; (2) those that relate the topic of S2 to that of S1. Fraser (1999) affirmed that his analysis has given some progress to the comprehension of what discourses markers are, although there is still much we do not understand. Subsequently, Fraser (2005, p. 209) proposed that discourse markers have the following properties: "they are free morphemes, are discourse-segment initial, signal a specific message, and are classified not syntactically but in terms of semantic/pragmatic functions". The author includes in the class of discourse markers only lexical expressions, excluding non-linguistic elements (gestures), syntactic structures and aspects of prosody (FRASER, 2005).

\footnotetext{
${ }^{1}$ In RST, there is no closed list of relationships. Originally, sixteen relationships (MANN; THOMPSON, 1986) were proposed, among which solutionhood, evidence, motivation, sequence, etc. But, more recently, other relationships have been proposed and can be found in Mann and Taboada (2015) and Carlson and Marcu (2001).
} 
Rossari (2000), who developed a semantic study of pragmatic connectives conjunctions, adverbs, and interjections -, says that the function of those elements is to signify a relation (the motivation for the term connectives) established between linguistic or contextual entities (the motivation for the term pragmatic). She adopted a doubly comparative approach, centered in the contrast between utterances with or without connectives and also in the contrast between utterances with connectives belonging to the same semantic class. According to her, this analysis can cause some impact in the way discursive relations are conceived, once the study of connectives considered as an autonomous place of meaning offers a particular elucidation to these relations. Unlike RST, Rossari considers that the pragmatic connective imposes a link between the segments adjacent to it and not just signals a relation. And she also says that there is a group of connectives, those that mark a non-paraphrase reformulation relation (like de toute façon and quoi qu'il en soit, for instance), which create a type of discourse relation that does not correspond to any cognitive primitives which found coherence relations (ROSSARI, 2000).

Researchers who adopted the Modular Approach to Discourse Analysis (the Geneva Model of discourse organization) as a theoretical and a methodological reference considered that discourse markers play a role in discourse organization. According to Roulet (2006), a research on discourse markers must be integrated in a global model of the complexity of the organization of monological and dialogical discourse. The description of discourse markers is, then, only a small part of the description of the overall and very complex organization of discourse. Besides, discourse markers, or text relation markers (TRM), apply to discourse constituents or relate discourse constituents to information stored in what Berrendonner (1983) calls discourse memory, defined as a set of knowledge shared by interlocutors. On Roulet's account, TRMs serve a discursive function due to the fact that they indicate a generic interactive relation. The indication of text relations and also the role a text relation marker plays in marking these relations is obtained through the study of the relational organization form of a text or dialogue.

Having looked briefly at these accounts, we can assume that pragmatic connectives do play a role in discourse organization and interpretation, by signaling a relationship between discourse segments, by signaling a relationship between discourse constituents and information stored in discourse memory, by constraining textual relations due to their conceptual and/or procedural meaning, and/or by signaling a relationship between discourse segments and context. On all of those accounts, connectives have a facilitating role in the interpretation process.

Thus, we chose to focus our analysis of the use of pragmatic connectives in texts of different genres based on the Geneva Model of discourse organization exposed in Roulet, Filliettaz and Grobet (2001) and in Filliettaz and Roulet (2002), due to the fact that this multidimensional approach is compatible with these different representations of the pragmatic connectives. Following Roulet (2001, 2003, 2006), we assume that the study of pragmatic connectives must be integrated in a global model of the complexity of the organization of monological and dialogical discourse. Due to the various analysis levels, the scope of connectives is analyzed in relation to the organization system - linguistic, textual and situational (the main ones) - taken into consideration. 
Considering the definition of pragmatic connective previously delineated, we start this presentation with a brief description of the Geneva Model of discourse organization and of the relational organization form. Afterwards, we present the analysis of the relational organization of the texts, which leads to the identification of textual relations, preceded by some remarks on the textual genres we are working on. After that, through the description of the relational profile of the texts, we discuss the observable differences between the organizations of texts of different genres in regard to the use of pragmatic connectives.

\section{THE GENEVA MODEL OF DISCOURSE AND THE RELATIONAL ORGANIZATION FORM}

The Geneva Model of discourse analysis consists of a theoretical and methodological instrument of discourse analysis, which combines information of different dimensions of discourse. Aligning with Bakhtin's proposals, discourse is conceived as a verbal interaction and it can be described "with reference to (a) the real situations in which it is used, (b) the textual configurations it gives rise to, and (c) the conventional resources it conveys and draws from" (FILLIETTAZ; ROULET, 2002, p. 374).

The authors postulate that discourse organization can be analyzed by initially identifying a restricted set of elementary components (modules) and afterwards combining these elementary elements (organization forms) in order to account for complex discourse processes.

The organization form that deals with discursive relations as well as with the pragmatic connectives contributions to their interpretation is the Relational Organization Form of Discourse. This organization form results of combining lexical, hierarchical and referential information. The study of the relational organization leads to the identification of relations - labeled illocutionary and interactive - that can exist between textual segments and implicit information stored in the discursive memory. These relations are defined relative to the process of negotiation subjacent to all interactions and exposed in a hierarchical structure.

The Geneva Model assumes that the construction of any verbal interaction or written text reflects a process of negotiation in which interlocutors recursively initiate propositions, react to them and ultimately ratify them ${ }^{2}$. A question, for instance, can be formulated in such a way that it will cause a reaction as simple as an answer, but it can also force the participants of an interaction to open a secondary negotiation in order to clarify what was in fact proposed. The reaction, in its turn, can be a complete answer so that it leads the participants to the ratification phase, or it can be a partial as well as a confusing answer. In this case, it will trigger the opening of another negotiation and so successively.

\footnotetext{
${ }^{2}$ In the modular approach, the proposition corresponds to the first intervention of an exchange and is characterized by establishing an illocutionary relationship with the following intervention: question, request, and assertion.
} 
With the intention of carrying out negotiations, interlocutors produce communicative constituents. Exchanges, which function as a maximal dialogical textual projection of a negotiation process, are composed of moves. Each phase of the negotiation process corresponds to a move, which can either be restricted to a main act or be formed by a more complex configuration: other moves or acts and exchanges that are subordinated to it. In order to define the constituents of the text, we clarify that, for the modular approach, the texts are formed by these three types of constituents (ROULET; FILLIETTAZ; GROBET, 2001):

\footnotetext{
Exchanges: each dialog can be analyzed into one or more exchanges.

Moves: each exchange can be analyzed into moves, linked by the initiative and/or reactive illocutionary functions which are generally attributed to speech acts; thus, a question move may be followed by an information/response move, which may in turn be followed by an evaluation move; a move is a functional unit that should not be confused with the formal dialog unit called "turn" by ethnomethodologists. Each move can be analyzed into a main act, possibly accompanied by exchanges, moves, or acts which are subordinated to it.

Acts: the text act is the minimal constituent of the hierarchical structure of a text.
}

In this approach, the negotiation process is represented by hierarchical structures, in which textual units can have a main status or a subordinate one. The main constituent is the one that holds the communicational value of the move.

The development and the ending of a negotiation process are associated with two distinct completion principles: (1) the principle of dialogical completion, which states that an exchange comes to an end when a double accord is achieved; (2) the principle of monological completion, which states that each constituent of an exchange should be formulated in order to be sufficiently clear so as to function as an adequate contribution to this process (ROULET; FILLIETTAZ; GROBET, 2001).

In a hierarchical structure, the illocutionary relations occur between information in the exchange level. The moves that compose an exchange can be linked by initiative or reactive illocutionary functions, such as question, request, answer, etc. In this approach, the illocutionary force is linked to the intervention and not to isolated acts. In other words, illocutionary force (question, request, assertion, etc.) characterizes not the isolated act, as in the theory of speech acts (AUSTIN, 1962, SEARLE, 1995), but the relation that an intervention (formed by one or many acts, interventions and exchanges) establishes with the information expressed in the following intervention and in the previous intervention (ROULET, 1980, 1999, ROULET; FILLIETTAZ; GROBET, 2001). According to Roulet (ROULET; FILLIETTAZ; GROBET, 2001, p. 169), "initiatives and reactive illocutionary relations do not characterize isolated acts, as in the theory of speech acts, but interventions that constitute exchanges, since questions, requests, etc. generally have complex structures."

The discursive constituents that belong to a move, in their turn, can be linked by interactive relations. The categories of interactive relations are: topicalization, preliminary, argument, counter-argument, comment, reformulation, succession, clarification (ROULET, 2003, 2006). These relationships are maneuvers with which the interactants can reach the principle of monological completion, elaborating an 
intervention that they consider satisfactory for the development of the interaction. Thus, the speaker or author, in establishing an interactive relationship (argument, counterargument, reformulation, etc.), evidences his attempt to produce an intervention that can be considered sufficiently complete by the other, who can develop the negotiation process, expressing his reaction or his ratification. These relations can often be identified by the presence of a connective or by the possibility of its insertion in the sequence, so as to turn explicit the interactive relation. There are interactive relations that can also be marked by a syntactic construction, like the left dislocation, which often occurs in topic constructions. There are others to which there can be no specific markers, like interactive relations of preliminary or commentary. In such cases, the determination of the interactive relations shall be made considering the position of the subordinate constituent, before or after the main constituent for preliminary or commentary ${ }^{3}$ respectively. The following list indicates the most common markers in Portuguese for each relation (MARINHO; CUNHA, 2012, p. 145):
a) argument: porque, pois, visto que, uma vez que, devido a, se, então, portanto etc.;
b) counter-argument: mas, porém, entretanto, no entanto, contudo, todavia, embora etc.;
c) reformulation: ou seja, ou melhor, enfim, finalmente, em suma, isto é, afinal, em todo caso etc.;
d) topicalization: quanto a, no que se refere a, com relação a, or left dislocation;
e) succession: em seguida, quando, depois (que), posteriormente, então etc;
f) preliminary: (no specific marker; the subordinate precedes the main constituent);
g) comment: (no specific marker; the subordinate follows the main constituent);
h) clarification: (no specific marker; it is the relation between a main constituent and the following subordinate exchange, if it opens with an interrogation).

The connectives that are present in a text (or that could be inserted in it) may function as guides to the reader, since they turn explicit many interactive relations. So, they contribute to the elucidation of text articulation by making evident the dominant relations inside its organization and the way it is constructed.

In the production of a text, we assume that the authors generally aims at expressing ideas and the way they relate to which other by using markers, that can be pragmatic connectives (such as adverbs, conjunctions) or even other mechanisms proceeding from different aspects of discourse organization (like sentence mood, verb tense, verb meaning, punctuation). As we have already pointed out, we focus our analysis on the use of pragmatic connectives and on the constraints these connectives impose on textual relations.

There always is an interactive relation between two constituents at the same level that can be or not marked by a connective. In this classification, se [if], porque [because], já que [as], uma vez que [since] and então [so], portanto [therefore], or mas [but], porém [however], apesar de [despite] and embora [although] indicate the same generic textual relation, argument or counter-argument respectively. Using this classification, we

\footnotetext{
3 According to Marinho (2002), the interactive relation of commentary can be marked by the relative pronouns that are used in act frontier. 
proceed to the description of the generic relations existent between the constituents in the texts.

As Roulet (2006) explained, the categories of textual relations are generic because each one covers a set of specific interactive relations. So, an argument relation, for instance, covers the following relations: cause (volitional and non volitional), explanation, justification, motivation, evidence, consequence, purpose, result (volitional and non volitional), argument, potential argument, polyphonic argument, decisive argument, accessory or minimal argument, exemplification. And a counter-argument relation covers the following relations: adversative, contrastive, concessive, opposition. Using these categories, it's possible to describe the generic textual relations between textual constituents and implicit information, stored in discursive memory.

In the relational analysis, the study of the specificities of each discursive relation is made with the application of an inferential calculation, which is based on the linguistic, hierarchical and referential properties of the constituents of the text. In this calculation, the linguistic information of the textual constituents functions as premises. In these premises, the linguistic information is enriched by the referents of pronouns and nominal expressions, like the agents that participate in the interaction and the other deictic elements (enriched logical form). If the relationship is marked by a connector, another premise is formulated based on the instruction (grammatical or pragmatic) of that connector. At the end of the calculation, with these premises, we obtain the conclusion or final interpretation about the specific relation considered (ROULET; FILLIETTAZ; GROBET, 2001, ROULET, 2003, 2006, MARINHO, 2002).

The description of the relational organization contributes to the elucidation of the interpretation of a text (through the interpretation of the dominant hierarchical positions of its constituents) and allows the achievement of its relational profile (shown in schemas we will present ahead), which turns evident the dominant relations inside its organization.

\section{SOME REMARKS ON JOURNALISTIC TEXTUAL GENRES}

Before the study of connectors and connective expressions identified in editorials and news, it is relevant to indicate, although succinctly, some referential properties of the studied genres. These properties will be useful to understanding the differences in the use of connective expressions in news and editorials.

Textual genres reflect in their linguistic materialization social relations, which influence the negotiation process, interlocutors intentions (such as inform, give an opinion, criticize, instruct, etc.), and also interlocutors perspectives (subjective or objective). Therefore, genres have a strong impact on the structuring of discourse and, in consequence, on the establishment of discourse relations and their signaling by pragmatic connectives (CUNHA, 2014, 2017).

The genres of the journalistic domain can play different communication functions in regard to their readers. Based on De Broucker, Adam (1997) notes that there are two main redaction journalistic genres that regroup the journalistic genre strictly speaking: the information genre (news, interview, portrait, newspaper report, etc.) and the commentary genre (editorial, chronicle, caricature, commentary article, etc.). 
Although we know that there are not clear boundaries between these categories, as pointed out by communication scholars (CHAPARRO, 2008; LAGE, 2009), we can consider them as two poles in a continuum list of journalistic textual genres (Figure 1). ${ }^{4}$

Figure 1 - Continuum list of journalistic textual genres

\begin{tabular}{|l|}
\hline Information genre pole \\
Newspaper report \\
News \\
Interview \\
Literary composition \\
Commentary article \\
Editorial \\
Chronicle \\
Commentary genre pole
\end{tabular}

So, we could say that an editorial, for instance, which is closer to the commentary genre pole, has as function to give an opinion about something or some subject that is in season. Its subject is an idea rather than a fact, and its writer intends to present an opinion rather than to report facts. And as Gauthier (2005) pointed out, editorials generally aim at persuading the readers; therefore they have an argumentative content and they are supposed to present a point of view sustained by a fundamental assumption. Considering all of this, we can hypothesize that opinion texts (editorials and commentary articles) tend to present arguments, explanation or justification of an idea from the writer's point of view, favouring mainly the instantiation of argument, counter-argument or reformulation relations.

But a textual genre like news, for instance, is closer to the information genre pole, for it is meant to inform and to give explanation about some fact that has recently happened. In presenting the news, we can hypothesize that the journalist tends to focus mainly on one subject and to present what has happened with evidential support and objectiveness, without expressing ostensibly her/his point of view. As Chaparro (2008, p. 182) pointed out, "News is the informative summary for the journalistic description of a relevant fact that exhausts in itself, and for whose understanding suffices the information the fact contains." ${ }^{5}$ In that case, we can hypothesize that the journalist may privilege preliminary or commentary relations.

\footnotetext{
${ }^{4}$ This scheme is inspired in Adam (1997).

5 "Notícia é o resumo informativo para a descrição jornalística de um fato relevante que se esgota em si mesmo, e para cuja compreensão bastam as informações que o próprio fato contém." (We translated every quotation from Portuguese.)

MARINHO, Janice Helena Chaves; CUNHA, Gustavo Ximenes. Investigating the role of pragmatic connectives in journalistic textual genres. Linguagem em (Dis)curso - LemD, Tubarão, SC, v. 18, n. 3, p. 545-563, set./dez. 2018.
} 
We examine the use of pragmatic connectives in texts of two different journalistic genres, aiming at understanding issues involved in discourse articulation. The data we are working on is composed by a set of authentic texts, written in Brazilian Portuguese. In this research, we selected opinion texts (editorials and commentary articles) and news. The texts were taken from Folha de S.Paulo (v. printed or online), since this newspaper has an expressive number of readers and is considered a reference newspaper in Brazil (MARTINS; LUCA, 2015).

The texts we examined can be interpreted as representing a reaction phase of a negotiation process, since each of them can be considered a reaction to a proposition, that is, a subject or a fact may trigger a necessity for a discussion, for an opinion or for information. So, we considered that each one of these texts constitutes a move which can be connected in interactive textual relations.

The opinion texts presented interactive relations marked by conventional connectives, coordinate or subordinate connectives (conjunctions listed in our traditional grammars, like: porque [because], pois [because], mas [but], porém [however], portanto [therefore], por isso [so], como [as], se [if] etc.). The authors used conventional connectives in order to signal the relations between adjacent sequences and information stored in discursive memory. Some connectors were employed more recurrently by the authors, such as the connector porque [because]:

1.[18] No Brasil, o enfoque dos "coitadinhos" se justifica mais que na França [19] porque o país há muito deixou de ser a terra das oportunidades. (ROSSI, Clóvis. Violência e inércia. Folha de S. Paulo. Opinião. Jun. 07, 2006. p. A2)

(In Brazil, the way of focusing the "poor guys" is more justifiable than in France because the country ceased to be the land of opportunities a long time ago. Anyway, the increase of violence demands, loudly, new ideas. )

In (1), the subordinate act introduced by the connector porque [because] justifies the main act that precedes the connector, as its hierarchical structure reveals ( $\mathrm{M}=$ move, $\mathrm{A}=$ act, $\mathrm{m}=$ main, $\mathrm{s}=$ subordinate, $\arg =$ argument $)$ :

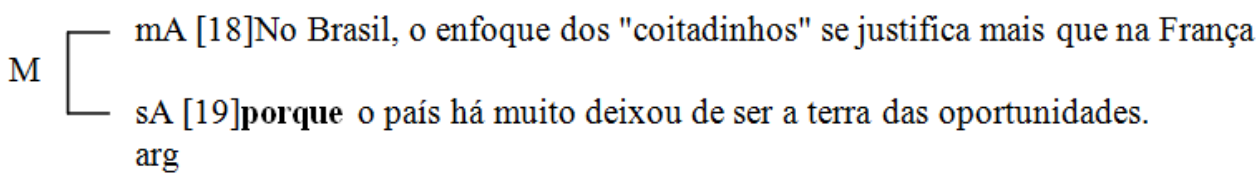

Thus, the author, in writing "porque o país há muito deixou de ser a terra das oportunidades" [because the country ceased to be the land of opportunities a long time ago], offers a reason to carry out the statement "No Brasil, o enfoque dos "coitadinhos" se justifica mais que na França" [In Brazil, the focus of the "poor guys" is justified more than in France]. And he signals the relation with porque as a marker of enunciative justification (MOESCHLER, 1998). 
But in their texts, it was also possible to find the use of phrase constructions assuming a connective function, like a reformulation or a justification, as seja como for [anyway] and do que dá prova [of what gives proof]. The expressions do que dá prova [of what gives proof] and seja como for [anyway] are less conventional. The first introduces an argument that not only can be understood as a "proof" (not formal, of course) for what was said in the act preceding the expression, but can also be used to justify a point of view previously expressed. This occurs in these excerpts:

2.[17] O diabo é que os fatos continuam a existir, [18] do que dá prova a frequiência com que o próprio presidente se diz vítima de seus amigos mais próximos. (ROSSI, Clóvis. O espelho e a indigência mental. Folha de S. Paulo.Opinião. São Paulo Nov. 5, 2006. p. A2)

(The problem is that the facts still exist, of what gives proof the frequency the president considers himself a victim of his closest friends.)

3.[25] O que não consigo entender é o conservadorismo generalizado no Brasil, [26] país que finge o tempo todo mudar tudo para deixar tudo como está, [27] como diria Giuseppe di Lampedusa. [28] É razoável conservar um sistema que se vai mostrando podre em todas as suas instâncias, [29] do que dá prova (apenas a mais recente) o envolvimento de figuras do Judiciário e do mundo jurídico com o crime organizado? (ROSSI, Clóvis. Conservadores do quê? Folha de S. Paulo. Opinião. São Paulo Abr. 22, 2007. p. A2)

(What I can't understand is the widespread conservatism in Brazil, country that pretends all the time to change everything so as to leave everything as it is, like Giuseppe di Lampedusa would say. It's reasonable to preserve a system which presents itself corrupted in all its instances, of what gives proof (only the most recent) the involvement of figures of the Judiciary and the legal world with the organized crime?)

As the expression do que dá prova [of what gives proof] introduces an argument, the constituent that it introduces is subordinate to the constituent that precedes it, as the hierarchical structure of the excerpt (2) reveals $(\mathrm{M}=$ move, $\mathrm{A}=$ act, $\mathrm{m}=$ main, $\mathrm{s}=$ subordinate, $\arg =$ argument).

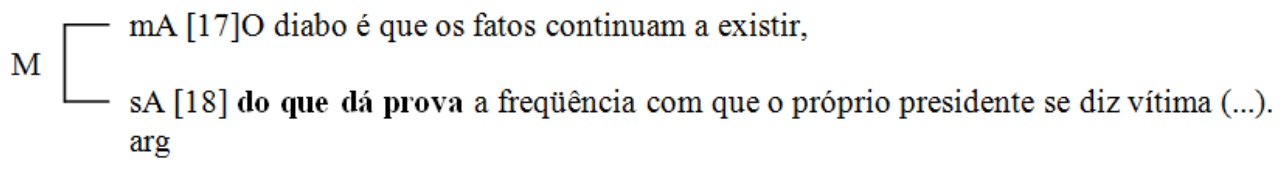

The second connective expression (seja como for [anyway]) signals an interactive reformulation relation. With this relation, the author indicates that the information introduced by the expression is more relevant than the information that precedes it ${ }^{6}$. As stated in Marinho and Cunha (2012), this expression imposes a non-causal relation between states of things expressed in the textual constituents and modifies the information state provided by the constituent that precedes the expression, because of the subtraction of information. This is evidenced by this excerpt:

\footnotetext{
${ }^{6}$ A more detailed description of the formal and functional properties of the connective expressions do que dá prova [of what gives proof] and seja como for [anyway] can be consulted in Marinho (2010) and Marinho; Cunha (2012).
}

MARINHO, Janice Helena Chaves; CUNHA, Gustavo Ximenes. Investigating the role of pragmatic connectives in journalistic textual genres. Linguagem em (Dis)curso - LemD, Tubarão, SC, v. 18, n. 3, p. 545-563, set./dez. 2018. 
4.[33] A CPMF possui características positivas: [34] é capaz de incidir sobre a economia informal [35] e funciona como um mecanismo auxiliar de controle à sonegação. [36] Bem diferente, contudo, é manter uma alíquota de $0,38 \%$ sobre movimentações financeiras, num país marcado simultaneamente pela altíssima carga tributária, pelo desperdício, pelo empreguismo e pela corrupção. [37] Não faltam sinais, sem dúvida, de que em última análise é tudo isto o que se pretende manter. [38] Seja como for, uma diminuição na alíquota da CPMF, [39] para nada dizer de iniciativas mais amplas de reforma do Estado e do sistema tributário, [40] não constitui ponto urgente nas negociações. (Realismo e disparate. Folha de S.Paulo. Editoriais. 21 set. 2007. p. A1)

(The CPMF has positive characteristics: it is able to focus on informal economy and it operates as an auxiliary mechanism of tax evasion control. Very different, however, is to maintain a rate of $0,38 \%$ on financial transactions, in a country marked simultaneously by the very high tax burden, waste, employment and corruption. There is no shortage of signs, of course, that all this is ultimately intended to be maintained. Anyway, a decrease in the CPMF rate, not to mention broader initiatives to reform the State and the tax system, does not constitute an urgent point in negotiations.)

In this excerpt, the intervention that precedes the expression seja como for [anyway] leads one to believe that the changes in the CPMF would be urgent. With the intervention introduced by the expression, this idea is reformulated, with the information that these changes are not considered urgent. Because the information introduced by the expression is more relevant than the information that precedes it, this expression introduces a main constituent, as the structure of the excerpt reveals. $(\mathrm{M}=$ move, $\mathrm{m}=$ main, $\mathrm{s}=$ subordinate, ref $=$ reformulation):

$\mathrm{M}$

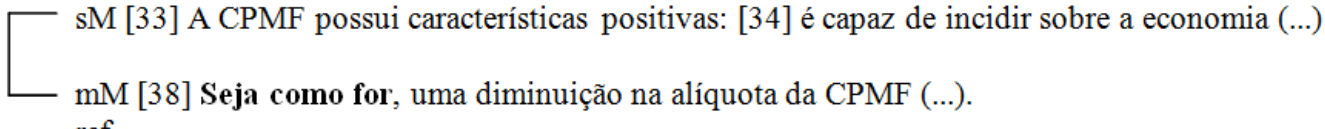
ref

There are many cases in which the absence of a connective turns difficult the interpretation of the textual relation. The absence of markers forces the reader to infer the textual relation existent in the sequences. It's interesting to remark that the absence of markers can often occur in opinion texts. In newspaper opinion texts there are many cases of contiguous sequences, and sometimes the absence of a connective interferes in the interpretation process of the relation, as we can see in the following example.

5.[1] Não venho acompanhando em detalhes a saia justa entre o pessoal da cultura, notadamente do cinema e do teatro, com o pessoal do esporte. [2] Alguns setores da sociedade acham descabida a obrigação do Estado de sustentar [3] ou apenas apoiar iniciativas culturais e esportivas. (CONY, Carlos Heitor. Folha de S.Paulo. Opinião. Dez. 17, 2006. p. A2)

(I have not been following in detail the delicate situation between the people of the culture, mainly from the cinema and from the theatre, and the people of the sports. Some sectors of the society consider inopportune the obligation of the State to patronize or only to support cultural and sportive initiatives.)

MARINHO, Janice Helena Chaves; CUNHA, Gustavo Ximenes. Investigating the role of pragmatic connectives in journalistic textual genres. Linguagem em (Dis)curso - LemD, Tubarão, SC, v. 18, n. 3, p. 545-563, set./dez. 2018. 
In order to interpret the relation between [1] and [2], in (5), we have to appeal to a third component, beside hierarchical and linguistic information: referential (or contextual) information. Since there is no connective between two text constituents, the specific textual relation must be interpreted inferentially by combining information given by both constituents on the basis of our world knowledge.

According to the Geneva Model, we can interpret this relation using a simple model of inference that links premises to a conclusion (Figure 2).

\section{Figure 2 - Inferential calculation}

\begin{tabular}{|l|l|l|}
\hline Premise 1 & $\begin{array}{l}\text { Linguistic information } \\
\text { (enriched logical form) }\end{array}$ & $\begin{array}{l}\text { The author says to the reader that he has not } \\
\text { been following in detail the delicate situation } \\
\text { between the people of the culture, mainly } \\
\text { from the cinema and from the theatre, and the } \\
\text { people of the sports. }\end{array}$ \\
\hline Premise 2 & $\begin{array}{l}\text { The author says to the reader that some } \\
\text { sectors of the society consider inopportune } \\
\text { the obligation of the State to patronize or only } \\
\text { to support cultural and sportive initiatives. }\end{array}$ \\
\hline Premise 3 & $\begin{array}{l}\text { It's known that some sectors of the society } \\
\text { consider inopportune the obligation of the } \\
\text { State to patronize or only to support cultural } \\
\text { and sportive initiatives. }\end{array}$ \\
\hline Conclusion & $\begin{array}{l}\text { Interpretation } \\
\text { (inferential calculation) }\end{array}$ & $\begin{array}{l}\text { The author says to the reader that he has not } \\
\text { been following in detail the delicate situation } \\
\text { between the people of the culture, mainly } \\
\text { from the cinema and from the theatre, and the } \\
\text { people of the sports but he knows that some } \\
\text { sectors of the society consider inopportune } \\
\text { the obligation of the State to patronize or only } \\
\text { to support cultural and sportive initiatives. }\end{array}$ \\
\hline
\end{tabular}

At the end of the inferential calculation, it is possible to assume that between [1] and [2] the speaker establishes a counter-argument relationship, which could have been signaled by but (mas), for instance.

This method allows us to informally compute the whole range of specific interactive relations in actual discourses by combining linguistic information given by the constituents and by the connectives (present in it or by means of its insertion in it) and contextual information. The absence of textual relation markers in a text leads the analyst to the application of these heuristic instruments so as to try to expose that interpretation process, which implies more cognitive efforts by the reader.

About the news, there was a predominance of comment or preliminary relations and there was, mainly in the journalists' texts, great presence of coordinate ${ }^{7}$ constituents. As discussed above, the relations of comment and preliminary are not characterized by sets of connectors or connective expressions. These relations are characterized by the position of the subordinate constituent in relation to the principal constituent. In the preliminary relation, the subordinate constituent precedes the principal, as this excerpt illustrates:

\footnotetext{
7 Two constituents are coordinated when they are hierarchically independent from each other, and an interactive relation does not relate them. 
6. [14] Armados de paus, pedras e blocos de cimento, [15] os sem-terra destruíram portas, paredes de vidro, equipamentos de informática, um busto de bronze do ex-governador Mário Covas, entre outras peças. (Da Folha Online. Invasão.)

(Armed with sticks, stones and pieces of concrete, the persons who claim a tract of land to work on destroyed doors, glass walls, informatics equipment, a Mário Covas' sculpture of bronze, between other things.)

In the excerpt, the subordinate act [14] establishes a preliminary relation with the main act [15] $(\mathrm{M}=$ move, $\mathrm{m}=$ main, $\mathrm{s}=$ subordinate, pre $=$ preliminary $)$ :

$\mathrm{M}$ sM [14] Armados de paus, pedras e blocos de cimento, pre $\mathrm{mM}[15]$ os sem-terra destruíram portas, paredes de vidro (...).

In the comment relation, the subordinate constituent succeeds the principal, as this other excerpt reveals:

7. [17]Vacilante e mais simplória, [18]a campanha do "sim" chegou a utilizar celebridades como Chico Buarque, Camila Pitanga e Maria Paula no início da campanha. [19]Mas na reta final, com tom mais elevado, buscou "satanizar" as armas e os interesses da indústria do setor. [20]No contra-ataque, Santa Rita apelou para imagens como a de Nelson Mandela na luta contra o "apartheid" na África do Sul e a do ministro da Justiça, Marcio Thomaz Bastos. [21]Nem Mandela nem Thomaz Bastos gostaram. (CLARICE SPITZ da Folha Online. Marketing foi "arma" para vitória do "não".)

(Vacillating and more silly, the "yes" campaign has used celebrities as Chico Buarque, Camila Pitanga and Maria Paula in its beginning. But in the final end, with a higher tone, it tried "to devil" the guns and the sector industry interests. In the counter-attack, Santa Rita appealed to images as the image of Nelson Mandela fighting against the apartheid in South Africa and the image of the minister of justice, Marcio Thomaz Bastos.)

In the excerpt, the subordinate act [21] brings a commentary on the main act [20] $(\mathrm{M}=$ move, $\mathrm{m}=$ main, $\mathrm{s}=$ subordinate, com = comment $)$ :

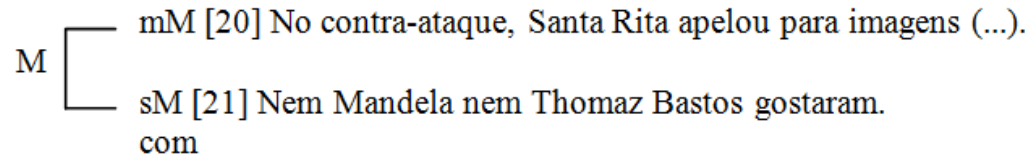

Despite the predominance of the comment and preliminary relations, we can find argument and counter-argument relations between some sequences, as shown in the following example.

8. [17] Vacilante e mais simplória, [18] a campanha do "sim" chegou a utilizar celebridades como Chico Buarque, Camila Pitanga e Maria Paula no início da campanha. [19] Mas na reta final, com tom mais elevado, buscou "satanizar" as armas e os interesses da indústria do setor. 
[20] No contra-ataque, Santa Rita apelou para imagens como a de Nelson Mandela na luta contra o "apartheid" na África do Sul e a do ministro da Justiça, Marcio Thomaz Bastos. [21] Nem Mandela nem Thomaz Bastos gostaram. [22] Mas tarde demais, [23] as imagens superaram as palavras. (CLARICE SPITZ da Folha Online. Marketing foi "arma" para vitória do "não".)

(Vacillating and more silly, the "yes" campaign has used celebrities as Chico Buarque, Camila Pitanga and Maria Paula in its beginning. But in the final end, with a higher tone, it tried "to devil" the guns and the sector industry interests. In the counter-attack, Santa Rita appealed to images as the image of Nelson Mandela fighting against the apartheid in South Africa and the image of the minister of justice, Marcio Thomaz Bastos. Neither Mandela nor Thomaz Bastos were pleased with it. But it was too late, the images excelled the words.)

In the excerpt, the two occurrences of the connector mas [but] introduce main constituents of the text, as revealed by its hierarchical structure $(\mathrm{M}=$ move, $\mathrm{m}=$ main, $\mathrm{s}$ $=$ subordinate, $\mathrm{c}-\mathrm{a}=$ counter-argument):

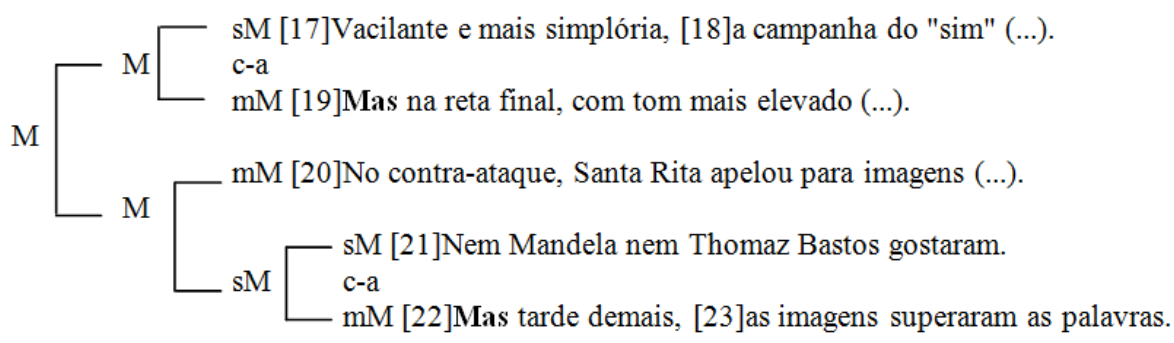

With the occurrences of the connector mas [but], the author introduces information that opposes the conclusions that could be drawn from the interventions that precede the connectors. With act [19] ("Mas na reta final, com tom mais elevado, buscou "satanizar" as armas e os interesses da indústria do setor" ["But in the final end, with a higher tone, it tried "to devil" the guns and the sector industry interests"]), the author opposes the idea that the campaign for disarmament remained faltering and simple. With act [22] ("Mas tarde demais" ["But it was too late"]), the author opposes the idea that the reaction of Mandela and Thomaz Bastos would have an impact on the campaign.

This example brings sequences that were situated in the middle or in the ending of the news, where we could find occasionally some discussion about the fact that was being informed beyond the presentation of details or implications due to this the fact.

It's worth mentioning that the most frequent connectives used in the news we examined are: the coordinate conjunction $e$ [and], with additive and also conclusive semantic values, the relative pronoun que [who/which] introducing appositive clauses, and also temporal expressions which are quite usual in narrative sequences, like em seguida [afterwards], quando [when], depois de [after], etc.

9. [7] Os 11 líderes do grupo, [8] que também serão autuados por tentativa de homicídio, [9] estão detidos no $2^{\circ}$ DP. (Da Folha Online. Invasão.)

(The 11 leaders of the group, who will also be sue for tentative of murder, are detained in the $2^{\text {nd }} D P$. .) 
10. [14] Armados de paus, pedras e blocos de cimento, [15] os sem-terra destruíram portas, paredes de vidro, equipamentos de informática, um busto de bronze do ex-governador Mário Covas, entre outras peças. [16] Um veículo, [17] que estava no saguão da Câmara [18] e seria sorteado na festa junina dos funcionários da Casa, [19] também foi destruído. (Da Folha Online. Invasão.)

(Armed with sticks, stones and pieces of concrete, the persons who claim a tract of land to work on destroyed doors, glass walls, informatics equipment, a Mário Covas' sculpture of bronze, between other things. A car, [16]that was in the entrance-hall of the Chamber of Deputies and that would be raffled in the popular June feast of the Chamber employees, was also destroyed.)

These excerpts illustrate a very common construction in journalists' news that consists in the use of a relative pronoun in act frontier, marking a comment interactive relation. With the comment relations, the journalist presents information necessary for the understanding of the events reported. In this sense, these relations help the journalist to produce an intervention that can be evaluated by the reader as adequate for the negotiation process.

11. [1] Embora tenham feito campanha pela vitória do "não" no referendo sobre a proibição do comércio de armas - [2] por questão de sobrevivência -, [3] as lojas que vendem armamento e munição em São Paulo só tiveram lucro extra nas duas semanas anteriores à votação. [4] Depois disso, mesmo com o comércio liberado, [5]o movimento tem reduzido bastante. (Após referendo, cai a venda de armas nas lojas. Folha de S.Paulo. Cotidiano. 21 nov.2005. p.C5)

(Although they had campaigned for the victory of "no" in the referendum on the prohibition of the commerce of weapons - for the sake of survival -, the stores that sell armament and ammunition in São Paulo only had extra profit in the two weeks prior to the vote. After this, even with the the trade released, the movement has been greatly reduced.)

In (11) there is an example of narrative sequences presented in news written by journalists. Hierarchical structure of these short example show textual constituents linked among them or to other constituents by a argument, counter-argument, succession interactive relations.

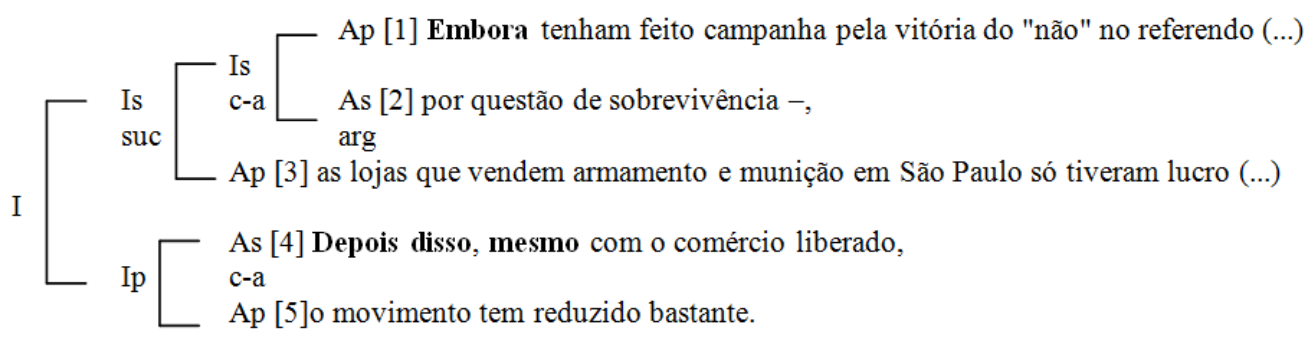

In this excerpt, connectors and connective expressions, as embora [although], depois disso [after this] and mesmo [even], are employed as interpretive guides. With these items, the journalist signals to the reader the counter-argument and succession relations present in the excerpt. 
In this paper we examined the use of pragmatic connectives in texts of journalistic genres (opinion texts and news) through the relational organization of these texts. We pointed out remarks on the choices made by the authors when they write their texts in regard to predominance of textual relations and linguistic markedness of textual relations, taking into consideration the proper differences between the two textual genres. We focus discourse markers as traces of strategic use made by writers in order to attain certain effects related to discourse structure.

As for the choices made by newspaper editorialists and journalists in the means of the markedness of textual relations, according to our corpus we would say that they do not use many connectives, which, as already seen, would guide the reader in the recognition of textual relations. We cannot say whether this is a deliberate choice or not. In order to discuss deeply their choices and all aspects of the relational organization of their texts, we would rather propose a future research on the use of other important discursive devices such as modal and evidential markers as well.

\section{REFERENCES}

ADAM, J. M. Unités rédactionnelles et genres discursifs: cadre général pour une approche de la presse écrite. Pratiques, n. 94, p. 3-18, 1997.

AUSTIN, J. L. How to do things with words. Oxford: Clarendon Press, 1962.

BERRENDONNER, A Connecteurs pragmatiques et anaphore. Cahiers de Linguistique Française, n. 5, p. 215-246, 1983.

BLAKEMORE, D. Understanding utterances: an introduction to pragmatics. Oxford: Blackwell, 1992.

CARLSON, L.; MARCU, D. Discourse tagging manual. Unpublished manuscript. 2001. Disponível em: <http://www.isi.edu/ marcu/discourse/tagging-ref-manual.pdf>. Acesso em: 13 set. 2017.

CHAPARRO, M. C. Sotaques d'aquém e d'além mar: travessias para uma nova teoria de gêneros jornalísticos. São Paulo: Summus, 2008.

CUNHA, G. X. As condições de emergência da função reformulativa do conector quando em reportagens. Revista de Estudos da Linguagem, v. 22, p. 143-170, 2014.

Conectores e processo de negociação: uma proposta discursiva para o estudo dos conectores.

Fórum Linguístico, v. 14, p. 1699-1716, 2017.

DUCROT, O. et al. Les mots du discours. Paris: Les Éditions de Minuit, 1980.

FILLIETTAZ, L.; ROULET, E. The Geneva Model of discourse analysis: an interactionist and modular approach to discourse organization. Discourse Studies, n. 4, p. 369-392, 2002.

FRASER, B. What are discourse markers? Journal of Pragmatics, n. 31, p. 931-952, 1999.

Towards a theory of discourse markers. In: FISCHER, K. (Org.) Approaches to discourse markers. Amsterdam: Elsevier, 2005, p. 209-226.

GAUTHIER, G. Argumentation et opinion dans la prise de position éditoriale. In: BURGER, M. ; MARTEL, G. (Orgs.) Argumentation et communication dans les médias. Québec: Éditions Nota bene, 2005. p. 131-155.

LAGE, N. A reportagem: teoria e técnica de entrevista e pesquisa jornalística. Rio de Janeiro: Record, 2009.

MANN, W. C.; THOMPSON, S. A. Relational propositions in discourse. Discourse Processes, v. 9, n. 1, p. 57-90, 1986.

Rhetorical Structure Theory: toward a functional theory of text organization. Text, v. 8, n. 3, p. 243-281, 1988.

MARINHO, Janice Helena Chaves; CUNHA, Gustavo Ximenes. Investigating the role of pragmatic connectives in journalistic textual genres. Linguagem em (Dis)curso - LemD, Tubarão, SC, v. 18, n. 3, p. 545-563, set./dez. 2018. 
MANN, W. C.; TABOADA, M. RST. 2015. Disponível em: < http://www.sfu.ca/rst/index.html>. 2015. Acesso em: 13 set. 2017.

MARINHO, J. H. C. O funcionamento discursivo do item "onde": uma abordagem modular. 2002. $305 f$. Tese (Doutorado em Linguística) - Faculdade de Letras, Universidade Federal de Minas Gerais, Belo Horizonte, 2002.

Estudo de uma expressão conectiva ocorrente no português brasileiro escrito. In: SARAIVA, M. E. F.; MARINHO, J. H. C. (Org.). Estudos da língua em uso: da gramática ao texto. Belo Horizonte: Editora UFMG, 2010. p. 171-189.

MARINHO, J. H. C.; CUNHA, G. X. O papel das expressões com efeito e seja como for na conexão textual. Mal-Estar e Sociedade, v. 5, p. 139-166, 2012.

MARTINS, A. L.; LUCA, T. R. História da impressa no Brasil. São Paulo: Contexto, 2015.

MOESCHLER, J. Les connecteurs pragmatiques. In: REBOUL, A.; MOESCHLER, J. Pragmatique du discours. De l'interprétation de l'énoncé à l'interprétation du discours. Paris: Armand Colin, 1998. p. 7598.

Connecteurs pragmatiques, inférences directionnelles et représentations mentales. In:

MOLENDIJK, A.; VET, C. (Org.) Temporalité et attitude. Structuration du discours et expression de la modalité. 2005. p. 35-50.

ROSSARI, C. Connecteurs et relations de discours: des liens entre cognition et signification. Nancy: Presses universitaires de Nancy, 2000.

ROULET, E. Strategies d'interaction, modes d'implicitation et marqueurs illocutoires. Cahiers de linguistique française, n. 1, , p. 80-103, 1980.

. La description de l'organisation du discours: du dialogue au texte. Paris: Didier, 1999.

De la necessité de distinguer des relations de discours sémantiques, textuelles et praxéologiques. Colloque internacional de l'Université d'Aarhus. 2001.

Une approche mudulaire de la problématique des relations de discours. In: MARI, H. et al. Análise do Discurso em Perspectivas. Belo Horizonte: FALE/UFMG, 2003. p. 149-178.

The description of text relation markers in the Geneva model of discourse organization. In: FISCHER, K. (Org.) Approaches to discourse particles. Amsterdam: Elsevier, 2006. p. 115-131.

ROULET E. ; FILLIETTAZ, L. ; GROBET, A. Un modèle et un instrument d'analyse de l'organisation du discours. Berne: Peter Lang, 2001.

SEARLE, J. R. Expressão e significado: estudos da teoria dos atos da fala. São Paulo: Martins Fontes, 1995.

SHIFFRIN, D. Discourse markers. Cambridge: Cambridge University Press, 1987.

TABOADA, M. Discourse markers as signal (or not) of rhetorical relations. Journal of Pragmatics, n. 38, p. 567-592, 2006.

VAN DIJK, T. A. Pragmatic connectives. Journal of Pragmatics, n. 3, p. 447-456, 1979.

\section{Recebido em: 13/09/17. Aprovado em: 17/04/18.}

Título: Investigando o papel de conectores pragmáticos em gêneros textuais jornalísticos Autores: Janice Helena Chaves Marinho; Gustavo Ximenes Cunha

Resumo: Este artigo examina o uso de conectores pragmáticos em textos de diferentes gêneros, buscando compreender a articulação do discurso e seu papel na construção de gêneros textuais. O corpus é composto por textos (escritos em português brasileiro) e produzidos por escritores brasileiros com elevado nível de proficiência linguística. Tomando o Modelo de Análise Modular do Discurso como arcabouço teórico central, considera que o estudo dos conectores pragmáticos deve ser integrado em um modelo global da complexidade da organização de discursos. Nesta perspectiva, apresenta a descrição da forma de organização relacional desses textos, uma vez que ela lida com as relações de discurso, bem como com o papel dos conectores pragmáticos na interpretação dessas relações. Portanto, por meio da descrição da organização relacional desses textos, discute as diferenças perceptíveis entre gêneros quanto ao uso dos conectores pragmáticos.

Palavras-chave: Gêneros jornalísticos. Abordagem modular. Conectores pragmáticos.

MARINHO, Janice Helena Chaves; CUNHA, Gustavo Ximenes. Investigating the role of pragmatic connectives in journalistic textual genres. Linguagem em (Dis)curso - LemD, Tubarão, SC, v. 18, n. 3, p. 545-563, set./dez. 2018. 
Título: Investigando el rol de conectores pragmáticos en géneros textuales periodísticos

Autores: Janice Helena Chaves Marinho; Gustavo Ximenes Cunha

Resumen: Este artículo examina el uso de conectores pragmáticos en textos de diferentes géneros, buscando comprender la articulación del discurso y su rol en la construcción de géneros textuales. El corpus es compuesto por textos (escritos en portugués brasileño) producidos por escritores brasileños con elevado nivel de competencia lingüística. Tomando el Modelo de Análisis Modular do Discurso como estructura teórica central, considera que el estudio de los conectores pragmáticos debe ser integrado en un modelo global da complejidad da organización de discursos. En esta perspectiva, presenta la descripción de la forma de organización relacional de eses textos, a vez que ella haz frente con las relaciones de discurso, así como con el rol de los conectores pragmáticos en la interpretación de esas relaciones. Por lo tanto, por medio de la descripción de la organización relacional de eses textos, discute las diferencias perceptibles entre géneros, cuanto al uso de los conectores pragmáticos.

Palabras clave: Géneros periodísticos. Abordaje modular. Conectores pragmáticos.

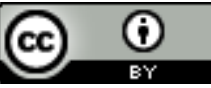

Este texto está licenciado com uma Licença Creative Commons Atribuição 4.0 Internacional.

MARINHO, Janice Helena Chaves; CUNHA, Gustavo Ximenes. Investigating the role of pragmatic connectives in journalistic textual genres. Linguagem em (Dis)curso - LemD, Tubarão, SC, v. 18, n. 3, p. 545-563, set./dez. 2018. 